\title{
PEMANFAATAN DATAMINING PADA PENGELOMPOKAN PROVINSI TERHADAP PENCEMARAN LINGKUNGAN HIDUP
}

\author{
Mawaddah Anjelita ${ }^{1}$, Agus Perdana Windarto ${ }^{2}$, Dedy Hartama ${ }^{3}$ \\ ${ }^{1}$ Sistem Informasi, STIKOM Tunas Bangsa Pematangsiantar \\ Email: ${ }^{1}$ anjelitamawaddah0@ gmail.com
}

\begin{abstract}
Abstrak
Penelitian ini bertujuan untuk memberi masukan bagi pemerintah agar segera dapat menanggulangi pencemaran air mengingat banyak dampak buruk yang mengintai dalam berbagai aspek kehidupan. Metode yang digunakan pada penelitian ini peneliti menggunakan metode algoritma datamining K-means Clustering. Data yang digunakan pada penelitian ini yaitu banyaknya desa/kelurahan menurut jenis pencemaran lingkungan hidup pada tahun 2018 yang terdiri dari 34 provinsi di Indonesia yang diperoleh melalui situs resmi Direktorat Badan Pusat Statistik. Variabel yang digunakan yaitu pencemaran air. Data dikelompokkan menjadi 2 cluster yaitu provinsi yang memiliki pencemaran air tingkat tinggi(C1) dan provinsi yang memiliki pencemaran air tingkat rendah(C2). Algoritma $K$-Means Clustering pada penelitian ini menghasilkan 2 iterasi, sehigga diperoleh hasil akhir yaitu: pencemaran air tingkat tinggi (C1) ada pada provinsi Sumatera Utara, Jawa Barat, Jawa Tengah, Jawa Timur, untuk pencemaran air tingkat rendah (C2) ada pada provinsi Aceh, Sumatera Barat, Riau, Jambi, Sumatera Selatan, Bengkulu, Lampung, Kep.Bangka Belitung, Kep.Riau, DKI Jakarta, DI Yogyakarta, Banten, Bali, Nusa Tenggara Barat, Nusa Tenggara Timur, Kalimantan Barat, Kalimantan Tengah, Kalimantan Selatan, Kalimantan Timur, Kalimantan Utara, Sulawesi Utara, Sulawesi Tengah, Sulawesi Selatan, Sulawesi Tenggara, Gorontalo, Sulawesi Barat, Maluku, Maluku Utara, Papua Barat, Papua.
\end{abstract}

Kata Kunci: Datamining, Clustering, K-means, Pencemaran Air

\section{Abstract}

This research aims to provide input for the government so that it can immediately tackle water pollution given the many adverse effects that lurk in various aspects of life. The method used in this study researchers used the method of K-means clustering datamining algorithm. The data used in this study are the number of villages according to the type of environmental pollution in 2018 which consists of 34 provinces in Indonesia obtained through the official website of the Directorate of Statistics Indonesia. The variable used is water pollution. The variable used is water pollution. Data is grouped into 2 clusters, namely provinces that have high levels of water pollution (C1) and provinces that have low levels of water pollution (C2). K-Means Clustering algorithm in this study produces 2 iterations, so the final result is: high water pollution (C1) in the provinces of North Sumatra, West Java, Central Java, East Java, for low level water pollution (C2) is in provinces of Aceh, West Sumatra, Riau, Jambi, South Sumatra, Bengkulu, Lampung, Kep.Bangka Belitung, Kep.Riau, DKI Jakarta, DI Yogyakarta, Banten, Bali, West Nusa Tenggara, East Nusa Tenggara, West Kalimantan, Central Kalimantan, South Kalimantan, East Kalimantan, North Kalimantan, North Sulawesi, Central Sulawesi, South Sulawesi, Southeast Sulawesi, Gorontalo, West Sulawesi, Maluku, North Maluku, West Papua, Papua.

Keywords:Datamining, Clustering, K-means, Water pollution

\section{PENDAHULUAN}

Lingkungan hidup adalah segala sesuatu yang ada disekitar makhluk hidup yang memiliki hubungan timbal balik serta mempunyai pengaruh terhadap keberlangsungan disekitarnya. Ada berbagai komponen lingkungan hidup diantaranya adalah manusia, hewan, tumbuhan, air, udara, dan lain sebagainya. Makluk hidup akan terus berinteraksi dengan lingkungan disekitar tempat tinggalnya. Kondisi lingkungan memiiki peran yang sangat penting dan saling berhubungan satu dengan yang lainnya dalam keberlangsungan ekosistem ini. Terciptanya lingkungan hidup yang berkualitas baik akan menjadikan manusia yang sehat. Ada banyak manfaat yang dapat diperloleh dari lingkungan hidup yang baik antara lain yaitu: (a) menciptakan sumber makanan, udara, rekreasi, obat-obatan, (b) menyerap karbondioksida (c) menjadi tempat menambah ilmu pengetahuan.

Tingginya tingkat populasi manusia menyebabkan meningkatnya akan berbagai kebutuhan. Kebutuhankebutuhan ini mengakibatkan kerusakan-kerusakan lingkungan yang terjadi diberbagai belahan dunia termasuk Indonesia. Salah satu kerusakan yang ditimbulkan yaitu pencemaran air pada lingkungan hidup. Air adalah bagian penting dalam kehidupan, tidak hanya bagi manusia tetapi juga hewan dan tumbuhan. Membuang sampah sembarangan, membuang limbah pabrik ke sungai, menangkap ikan menggunakan bahan peledak, kurangnya pengetahuan akan pentingnya air menjadi penyebab air menjadi tercemar dan masih banyak penyebab lainnya. Air yang telah tercemar memiliki ciri-ciri seperti : (a) air keruh, (b) air memiliki rasa yang aneh serta berbau, (c) air yang tercemar akan meninggalkan noda, (d) terdapat endapan, (e) $\mathrm{pH}$ air tidak netral. Untuk mengukur sehat atau tidaknya air dapat menggunakan indikator seperti warna air, bau air, rasa air, derajat keasaman air, suhu air. Banyak dampak buruk yang akan terjadi jika pencemaran air ini tidak mendapat penanganan, antaralain seperti: berkurangnya ketersediaan air bersih, diare, disentri, hepatitis A, keracunan, rusaknya ekosistem daerah perairan, merusak tanaman, kerugian pada nelayan dan masih banyak lagi.

Banyak cabang ilmu komputer yang dapat menyelesaikan masalah secara kompleks. Mereka masuk dalam cabang ilmu artificial inteligence (AI) diantaranya sistem pendukung keputusan [1]-[5], datamining [6]-[9], sistem pakar [10], jaringan saraf tiruan [11]-[14], algoritma genetika [15] dan lain-lain. Cabang ilmu tersebut semuanya masuk kedalam artificial inteligence (AI). Penelitian ini menggunakan metode Data mining. Data mining merupakan 
analisa terhadap data untuk menemukan hubungan yang jelas serta menyimpulkannya yang belum diketahui sebelumnya dengan cara terkini dipahami dan berguna bagi pemilik data tersebut. Secara sederhana data mining biasa dikatakan sebagai proses penyaring atau "menambang" pengetahuan dari sejumlah data yang besar. Istilah lain untuk data mining adalah Knowlegde Discoveryin Database (KDD) [16]. Clustering adalah salah satu metode dimana penyelesaiannya menggunakan kesamaan yang telah ditentukan dalam membagi data dalam jumlah banyak. Dengan adanya cluster, pola-pola tertentu dalam terdistribusikan secara keseluruhan yang memiliki hubungan. Data yang memiliki persamaan yang tinggi akan dikelompokkan menjadi 2 atau lebih cluster. K-means adalah bagian data clustering, dimana pada k-means data yang ada dalam satu bentuk dikelompokkan menjadi beberapa bagian dengan menggunakan jarak terdekat.

\section{TEORITIS}

\subsection{Data Mining}

Data mining yang juga dikenal dengan istilah pattern recognition merupakan suatu metode yang digunakan untuk pengolahan data guna menemukan pola yang tersembunyi dari data yang diolah. Data yang diolah dengan teknik data mining ini kemudian menghasilkan suatu pengetahuan baru yang bersumber dari data lama [17]. Data mining adalah suatu metode pengolahan data untuk menemukan pola yang tersembunyi dari data tersebut. Hasil dari pengolahan data dengan metode data mining ini dapat digunakan untuk mengambil keputusan di masa depan[18].

\subsection{Clustering}

Clustering merupakan suatu metode untuk mencari dan mengelompokkan data yang memiliki kemiripan karakteristik (similarity) antara satu data dengan data yang lain. Tujuan utama dari metode clustering adalah pengelompokan sejumlah data atau obyek ke dalam cluster (group) sehingga dalam setiap cluster dapat berisi data yang semirip mungkin. Dalam clustering metode ini berusaha untuk menempatkan obyek yang mirip (jaraknya dekat) dalam satu cluster dan membuat jarak antar cluster sejauh mungkin. Ini berarti obyek dalam satu cluster sangat mirip satu dengan lain dan berbeda dengan obyek dalam cluster-cluster yang lain[18].

\subsection{K-Means}

K-Means menguji masing-masing komponen di dalam populasi data dan menandai komponen tersebut ke salah satu pusat cluster yang telah didefinisikan tergantung dari jarak minimum antar komponen dengan tiap-tiap cluster. Posisi pusat cluster akan dihitung kembali sampai semua komponen data digolongkan kedalam tiap-tiap pusat cluster dan terakhir akan terbentuk posisi pusat cluster yang baru[16]. Algoritma ini mampu meminimalkan jarak data dengan cluster yang akan dikelompokkan. Algoritma K-Means merupakan metode nonheirarchial yang pada awalnya mengambil sebagian dari banyaknya komponen dari populasi untuk dijadikan pusat cluster awal. Langkah awal pada metode $K$-Means clustering yaitu mencari titik pusat (centroid) pada cluster, selanjutnya dengan adanya titik pusat tersebut data akan diolah, sehingga diambil hasil minimum (jarak cluster terpendek) dari data pada setiap cluster. Centroid pada K-Mens Clustering berupa nilai[19].

\section{METODE PENELITIAN}

\subsection{Tahap Pengumpulan Data}

Dalam pemanfaatan datamining pada pengelompokan provinsi terhadap pencemaran lingkungan diperlukan data yang terkait akan hal tersebut. Data dalam penelitian ini diambil melalui situs resmi Direktorat Badan Pusat Statistik (https://www.bps.go.id). Data yang digunakan pada penelitian ini adalah banyaknya desa/kelurahan menurut jenis pencemaran lingkungan hidup pada tahun 2018 yang terdiri dari 34 provinsi di Indonesia. Variabel yang digunakan yaitu pencemaran air. Data akan diolah menjadi 2 cluster, yaitu provinsi yang memiliki pencemaran air tingkat tinggi dan provinsi yang memiliki pencemaran air tingkat rendah.

\subsection{Tahap Pengolahan Data}

Data yang telah diperoleh akan diolah terlebih dahulu. Pada tahap pengolahan data ini, data akan dihitung sesuai dengan ketentuan algoritma $K$-means clustering sehingga akan diperoleh pengelompokan-pengelompokan data (cluster).

\subsection{Clustering}

Analisa cluster merupakan teknik multivariat yang mempunyai tujuan utama untuk mengelompokan objekobjek berdasarkan karakteristik yang cluster dimilikinya. Analisis mengklasifikasikan objek sehingga setiap objek yang paling dekat kesamaannya dengan objek lain berada dalam cluster yang sama[20]. Menurut Baskoro clustering atau klusterisasi adalah salah satu alat bantu pada data mining yang bertujuan mengelompokkan objek-objek ke dalam cluster-cluster. Cluster adalah sekelompok atau sekumpulan objek - objek data yang similar satu sama lain dalam 
cluster yang sama dan disimilar terhadap objek-objek yang berbeda cluster[21]. Dalam tahap cluster dibutuhkan flowchart yang berfungsi sebagai rangkaian alur untuk memudahkan dalam perhitungan terhadap data yang akan diproses. Berikut ini adalah flowchart dalam menentukan K-means clustering.

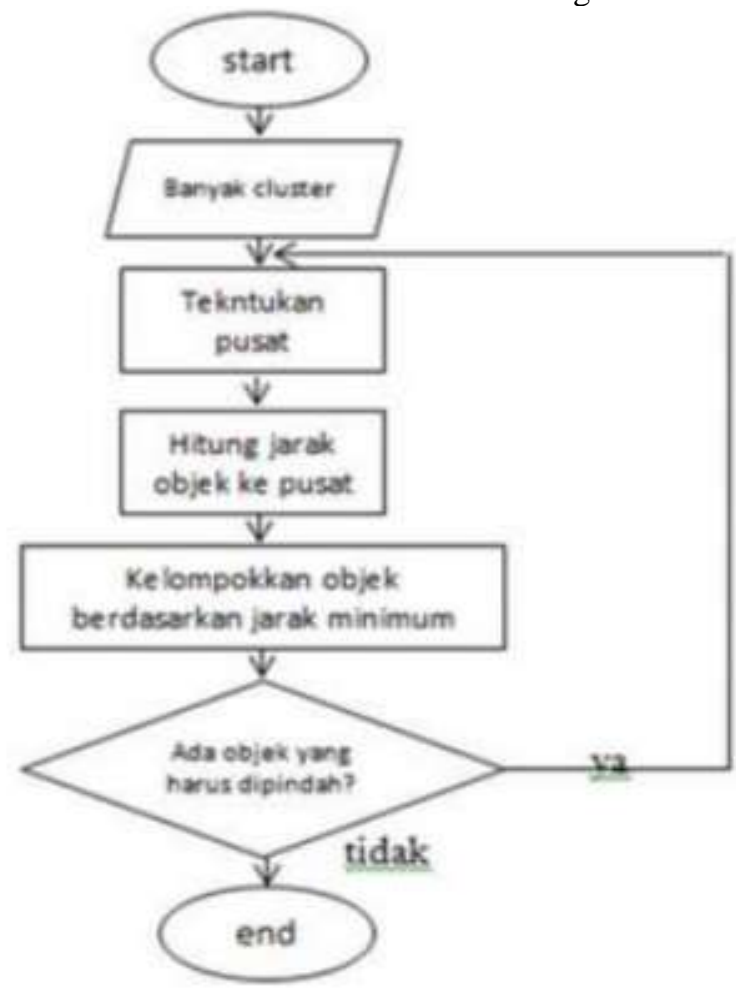

Gambar 1. Flowchart Clustering

\subsection{Tahap Analisis}

Data yang telah diperoleh akan diolah dengan menggunakan perhitungan bobot dari setia indeks. Pada tahap sebelumnya telah ditentukan kedalam 2 cluster, yaitu cluster tingkat pencemaran air tinggi, dan cluster tingkat pencemaran air rendah. Pada tahap inilah data akan dianalisis hasilnya.

\section{HASIL DAN PEMBAHASAN}

Pada algoritma clustering, data yang telah diperoleh akan dihitung terlebih dahulu berdasarkan banyaknya desa/kelurahan menurut jenis pencemaran lingkungan hidup pada tahun 2018. Hasil perhitungan berdasarkan variabel pencemaran air yang tertera pada tabel 1 .

Tabel 1. Data Pencemaran air tahun 2018

\begin{tabular}{clr}
\hline No. & Provinsi & Pencemaran Air \\
\hline 1 & Aceh & 729 \\
2 & Sumatera Utara & 1205 \\
3 & Sumatera Barat & 319 \\
4 & Riau & 454 \\
5 & Jambi & 614 \\
6 & Sumatera Selatan & 673 \\
7 & Bengkulu & 286 \\
8 & Lampung & 572 \\
9 & Kep. Bangka Belitung & 159 \\
10 & Kep. Riau & 55 \\
11 & DKI Jakarta & 126 \\
12 & Jawa Barat & 1890 \\
13 & Jawa Tengah & 1900 \\
14 & DI Yogyakarta & 99 \\
15 & Jawa Timur & 1643 \\
16 & Banten & 513 \\
17 & Bali & 130 \\
18 & Nusa Tenggara Barat & 282 \\
19 & Nusa Tenggara Timur & 122 \\
20 & Kalimantan Barat & 915
\end{tabular}




\begin{tabular}{lll}
21 & Kalimantan Tengah & 782 \\
22 & Kalimantan Selatan & 714 \\
23 & Kalimantan Timur & 318 \\
24 & Kalimantan Utara & 139 \\
25 & Sulawesi Utara & 327 \\
26 & Sulawesi Tengah & 303 \\
27 & Sulawesi Selatan & 400 \\
28 & Sulawesi Tenggara & 227 \\
29 & Gorontalo & 111 \\
30 & Sulawesi Barat & 115 \\
31 & Maluku & 105 \\
32 & Maluku Utara & 216 \\
33 & Papua Barat & 155 \\
34 & Papua & 249 \\
\hline
\end{tabular}

Data yang telah diperoleh selanjutnya akan diproses dengan menggunakan aplikasi rapidminer sebanyak 2 cluster dengan menerapkan algoritma k-means.

\subsection{Input Data}

Data yang telah diperoleh selanjutnya akan diaplikasikan ke tool rapidminer dengan menggunakan 2 cluster. Sehingga hasil yang diperoleh dapat dilihat pada gambar 2 dan gambar 3.

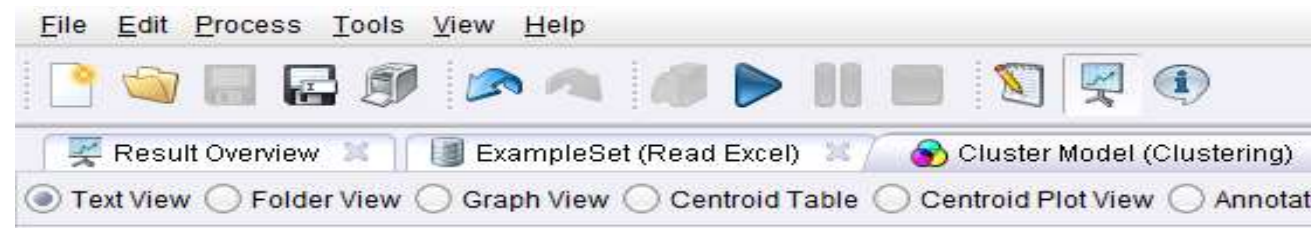

\section{Cluster Model}

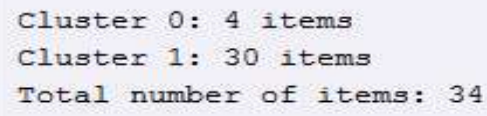

Gambar 2. Hasil Rapidminer

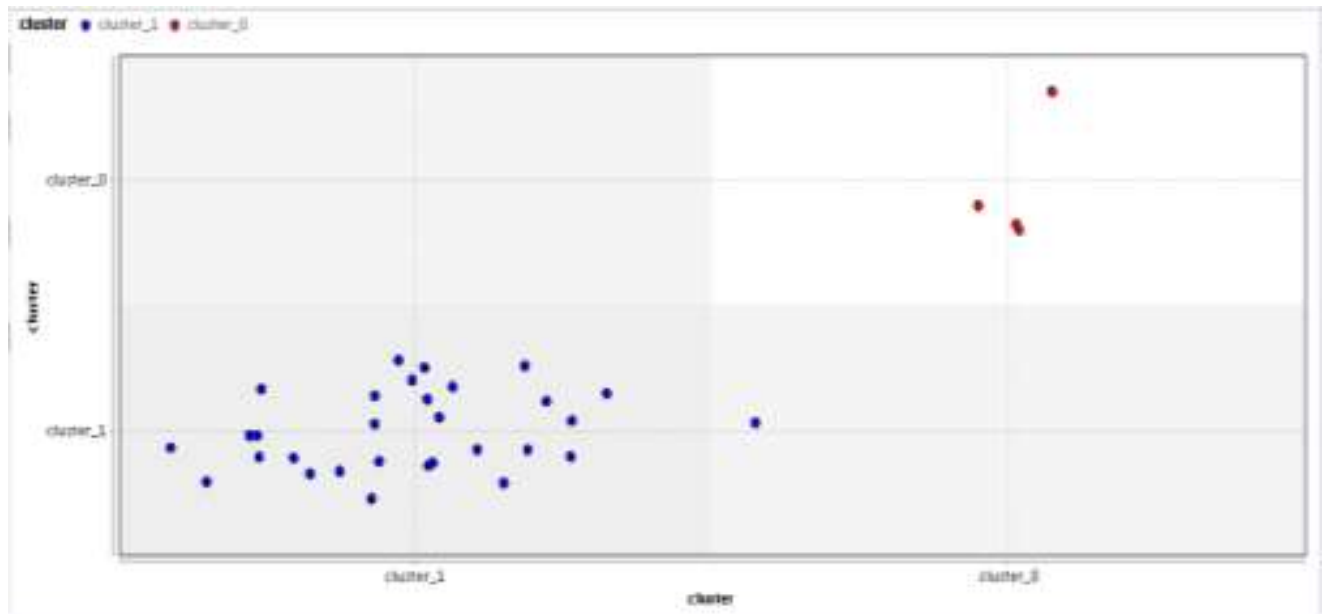

Gambar 3. Pengelompokan Rapidminer Menggunakan 2 Cluster

\subsection{Centroid Data}

Dalam menggunakan algoritma $K$-means clustering diperlukan nilai centroid atau nilai titik tengah yang berfungsi sebagai awal untuk menentukan cluster yang diinginkan. Pada penelitian ini peneliti menggunakan 2 cluster yaitu pencemaran air tingkat tinggi $(\mathrm{C} 1)$ dan pencemaran air tingkat rendah $(\mathrm{C} 2)$. Nilai centroid $\mathrm{C} 1$ ditentukan dengan 
menggunakan nilai maksimum atau nilai terbesar dan untuk nilai C2 ditentukan dengan menggunakan nilai minimun atau nilai terkecil. Sehingga nilai centroid dapat dilihat pada tabel 2

Tabel 2. Nilai Centroid Awal Iterasi 1

\begin{tabular}{cc}
\hline Atribut & Nilai \\
\hline $\mathrm{C} 1=$ Tinggi & 1900 \\
$\mathrm{C} 2=$ Rendah & 55 \\
\hline
\end{tabular}

\subsection{Clustering Data}

Setelah nilai centroid telah didapat, langkah selanjutnya yaitu clusterisasi data. Proses perhitungan menggunakan jarak terdekat dari data yang telah diolah sehingga menghasilkan iterasi 1. Pada iterasi 1 menghasilkan pengelompokan data yaitu: untuk pencemaran air tingkat tinggi $(\mathrm{C} 1)$ ada pada provinsi Sumatera Utara, Jawa Barat, Jawa Tengah, Jawa Timur, untuk pencemaran air tingkat rendah (C2) ada pada provinsi Aceh, Sumatera Barat, Riau, Jambi, Sumatera Selatan, Bengkulu, Lampung, Kep.Bangka Belitung, Kep.Riau, DKI Jakarta, DI Yogyakarta, Banten, Bali, Nusa Tenggara Barat, Nusa Tenggara Timur, Kalimantan Barat, Kalimantan Tengah, Kalimantan Selatan, Kalimantan Timur, Kalimantan Utara, Sulawesi Utara, Sulawesi Tengah, Sulawesi Selatan, Sulawesi Tenggara, Gorontalo, Sulawesi Barat, Maluku, Maluku Utara, Papua Barat, Papua.

Tabel 3. Perhitungan Jarak Pusat Cluster Iterasi 1

\begin{tabular}{|c|c|c|c|c|c|}
\hline No. & Provinsi & Pencemaran Air & C1 & $\mathrm{C2}$ & Jarak Terpendek \\
\hline 1 & Aceh & 729 & 1171 & 674 & 674 \\
\hline 2 & Sumatera Utara & 1205 & 695 & 1150 & 695 \\
\hline 3 & Sumatera Barat & 319 & 1581 & 264 & 264 \\
\hline 4 & Riau & 454 & 1446 & 399 & 399 \\
\hline 5 & Jambi & 614 & 1286 & 559 & 559 \\
\hline 6 & Sumatera Selatan & 673 & 1227 & 618 & 618 \\
\hline 7 & Bengkulu & 286 & 1614 & 231 & 231 \\
\hline 8 & Lampung & 572 & 1328 & 517 & 517 \\
\hline 9 & Kep. Bangka Belitung & 159 & 1741 & 104 & 104 \\
\hline 10 & Kep. Riau & 55 & 1845 & 0 & 0 \\
\hline 11 & DKI Jakarta & 126 & 1774 & 71 & 71 \\
\hline 12 & Jawa Barat & 1890 & 10 & 1835 & 10 \\
\hline 13 & Jawa Tengah & 1900 & 0 & 1845 & 0 \\
\hline 14 & DI Yogyakarta & 99 & 1801 & 44 & 44 \\
\hline 15 & Jawa Timur & 1643 & 257 & 1588 & 257 \\
\hline 16 & Banten & 513 & 1387 & 458 & 458 \\
\hline 17 & Bali & 130 & 1770 & 75 & 75 \\
\hline 18 & Nusa Tenggara Barat & 282 & 1618 & 227 & 227 \\
\hline 19 & Nusa Tenggara Timur & 122 & 1778 & 67 & 67 \\
\hline 20 & Kalimantan Barat & 915 & 985 & 860 & 860 \\
\hline 21 & Kalimantan Tengah & 782 & 1118 & 727 & 727 \\
\hline 22 & Kalimantan Selatan & 714 & 1186 & 659 & 659 \\
\hline 23 & Kalimantan Timur & 318 & 1582 & 263 & 263 \\
\hline 24 & Kalimantan Utara & 139 & 1761 & 84 & 84 \\
\hline 25 & Sulawesi Utara & 327 & 1573 & 272 & 272 \\
\hline 26 & Sulawesi Tengah & 303 & 1597 & 248 & 248 \\
\hline 27 & Sulawesi Selatan & 400 & 1500 & 345 & 345 \\
\hline 28 & Sulawesi Tenggara & 227 & 1673 & 172 & 172 \\
\hline 29 & Gorontalo & 111 & 1789 & 56 & 56 \\
\hline 30 & Sulawesi Barat & 115 & 1785 & 60 & 60 \\
\hline 31 & Maluku & 105 & 1795 & 50 & 50 \\
\hline 32 & Maluku Utara & 216 & 1684 & 161 & 161 \\
\hline 33 & Papua Barat & 155 & 1745 & 100 & 100 \\
\hline 34 & Papua & 249 & 1651 & 194 & 194 \\
\hline
\end{tabular}

Tabel 4. Pengelompokan Data Iterasi 1

\begin{tabular}{clrr}
\hline No. & \multicolumn{1}{c}{ Provinsi } & C1 & C2 \\
\hline 1 & Aceh & & 1 \\
2 & Sumatera Utara & 1 & \\
3 & Sumatera Barat & & 1 \\
4 & Riau & & 1 \\
5 & Jambi & & 1 \\
6 & Sumatera Selatan & & 1 \\
7 & Bengkulu & 1 \\
8 & Lampung & 1 \\
9 & Kep. Bangka Belitung & & 1
\end{tabular}




\begin{tabular}{|c|c|c|}
\hline 10 & Kep. Riau & \\
\hline 11 & DKI Jakarta & \\
\hline 12 & Jawa Barat & 1 \\
\hline 13 & Jawa Tengah & 1 \\
\hline 14 & DI Yogyakarta & \\
\hline 15 & Jawa Timur & 1 \\
\hline 16 & Banten & \\
\hline 17 & Bali & \\
\hline 18 & Nusa Tenggara Barat & \\
\hline 19 & Nusa Tenggara Timur & \\
\hline 20 & Kalimantan Barat & \\
\hline 21 & Kalimantan Tengah & \\
\hline 22 & Kalimantan Selatan & \\
\hline 23 & Kalimantan Timur & \\
\hline 24 & Kalimantan Utara & \\
\hline 25 & Sulawesi Utara & \\
\hline 26 & Sulawesi Tengah & \\
\hline 27 & Sulawesi Selatan & \\
\hline 28 & Sulawesi Tenggara & \\
\hline 29 & Gorontalo & \\
\hline 30 & Sulawesi Barat & \\
\hline 31 & Maluku & \\
\hline 32 & Maluku Utara & \\
\hline 33 & Papua Barat & \\
\hline 34 & Papua & \\
\hline
\end{tabular}

Pada algoritma K-means, data akan terus beritersi sampai antara iterasi sebelum dan iterasi saat ini sama(tidak ada perubahan pengelompokan. Selanjutnya pada iterasi 2 data diproses kembali dengan menggunakan nilai centroid baru. Nilai centroid baru ditentukan dengan menggunakan data pada cluster iterasi 1 . Nilai centroid iterasi 2 dapat dilihat pada tabel 5.

Tabel 5. Nilai Centroid Baru Iterasi 2

\begin{tabular}{cc}
\hline Atribut & \multicolumn{1}{c}{ Nilai } \\
\hline C1=Tinggi & 1660 \\
C2=Rendah & 340 \\
\hline
\end{tabular}

Setelah nilai centroid baru didapat, lakukan kembali seperti iterasi 1 tetapi dengan menggunakan nilai centroid yang baru. Pengelompokan data menggunakan jarak terpendek, sehingga diperoleh iterasi 2 pada tabel 6 .

Tabel 6. Perhitungan Jarak Pusat Cluster Iterasi 2

\begin{tabular}{clrrrr}
\hline No. & \multicolumn{1}{c}{ Provinsi } & Pencemaran Air & \multicolumn{1}{c}{ C1 } & \multicolumn{1}{c}{ C2 } & Jarak Terpendek \\
\hline 1 & Aceh & 729 & 930,5 & 388,7 & 388,7 \\
2 & Sumatera Utara & 1205 & 454,5 & 864,7 & 454,5 \\
3 & Sumatera Barat & 319 & 1340,5 & 21,3 & 21,3 \\
4 & Riau & 454 & 1205,5 & 113,7 & 113,7 \\
5 & Jambi & 614 & 1045,5 & 273,7 & 273,7 \\
6 & Sumatera Selatan & 673 & 986,5 & 332,7 & 332,7 \\
7 & Bengkulu & 286 & 1373,5 & 54,3 & 54,3 \\
8 & Lampung & 572 & 1087,5 & 231,7 & 231,7 \\
9 & Kep. Bangka Belitung & 159 & 1500,5 & 181,3 & 181,3 \\
10 & Kep. Riau & 55 & 1604,5 & 285,3 & 285,3 \\
11 & DKI Jakarta & 126 & 1533,5 & 214,3 & 214,3 \\
12 & Jawa Barat & 1890 & 230,5 & 1549,7 & 230,5 \\
13 & Jawa Tengah & 1900 & 240,5 & 1559,7 & 240,5 \\
14 & DI Yogyakarta & 99 & 1560,5 & 241,3 & 241,3 \\
15 & Jawa Timur & 1643 & 16,5 & 1302,7 & 16,5 \\
16 & Banten & 513 & 1146,5 & 172,7 & 172,7 \\
17 & Bali & 130 & 1529,5 & 210,3 & 210,3 \\
18 & Nusa Tenggara Barat & 282 & 1377,5 & 58,3 & 58,3 \\
19 & Nusa Tenggara Timur & 122 & 1537,5 & 218,3 & 218,3 \\
20 & Kalimantan Barat & 915 & 744,5 & 574,7 & 574,7 \\
21 & Kalimantan Tengah & 782 & 877,5 & 441,7 & 441,7 \\
22 & Kalimantan Selatan & 714 & 945,5 & 373,7 & 373,7 \\
23 & Kalimantan Timur & 318 & 1341,5 & 22,3 & 22,3 \\
24 & Kalimantan Utara & 139 & 1520,5 & 201,3 & 201,3 \\
25 & Sulawesi Utara & 327 & 1332,5 & 13,3 & 13,3 \\
26 & Sulawesi Tengah & 303 & 1356,5 & 37,3 & 37,3
\end{tabular}




\begin{tabular}{llrrrr}
27 & Sulawesi Selatan & 400 & 1259,5 & 59,7 & 59,7 \\
28 & Sulawesi Tenggara & 227 & 1432,5 & 113,3 & 113,3 \\
29 & Gorontalo & 111 & 1548,5 & 229,3 & 229,3 \\
30 & Sulawesi Barat & 115 & 1544,5 & 225,3 & 225,3 \\
31 & Maluku & 105 & 1554,5 & 235,3 & 235,3 \\
32 & Maluku Utara & 216 & 1443,5 & 124,3 & 124,3 \\
33 & Papua Barat & 155 & 1504,5 & 185,3 & 185,3 \\
34 & Papua & 249 & 1410,5 & 91,3 & 91,3 \\
\hline
\end{tabular}

Tabel 7. Pengelompokan Data Iterasi 2

\begin{tabular}{|c|c|c|c|}
\hline No. & Provinsi & $\mathrm{C} 1$ & $\mathrm{C} 2$ \\
\hline 1 & Aceh & & 1 \\
\hline 2 & Sumatera Utara & 1 & \\
\hline 3 & Sumatera Barat & & 1 \\
\hline 4 & Riau & & 1 \\
\hline 5 & Jambi & & 1 \\
\hline 6 & Sumatera Selatan & & 1 \\
\hline 7 & Bengkulu & & 1 \\
\hline 8 & Lampung & & 1 \\
\hline 9 & Kep. Bangka Belitung & & 1 \\
\hline 10 & Kep. Riau & & 1 \\
\hline 11 & DKI Jakarta & & 1 \\
\hline 12 & Jawa Barat & 1 & \\
\hline 13 & Jawa Tengah & 1 & \\
\hline 14 & DI Yogyakarta & & 1 \\
\hline 15 & Jawa Timur & 1 & \\
\hline 16 & Banten & & 1 \\
\hline 17 & Bali & & 1 \\
\hline 18 & Nusa Tenggara Barat & & 1 \\
\hline 19 & Nusa Tenggara Timur & & 1 \\
\hline 20 & Kalimantan Barat & & 1 \\
\hline 21 & Kalimantan Tengah & & 1 \\
\hline 22 & Kalimantan Selatan & & 1 \\
\hline 23 & Kalimantan Timur & & 1 \\
\hline 24 & Kalimantan Utara & & 1 \\
\hline 25 & Sulawesi Utara & & 1 \\
\hline 26 & Sulawesi Tengah & & 1 \\
\hline 27 & Sulawesi Selatan & & 1 \\
\hline 28 & Sulawesi Tenggara & & 1 \\
\hline 29 & Gorontalo & & 1 \\
\hline 30 & Sulawesi Barat & & 1 \\
\hline 31 & Maluku & & 1 \\
\hline 32 & Maluku Utara & & 1 \\
\hline 33 & Papua Barat & & 1 \\
\hline 34 & Papua & & \\
\hline
\end{tabular}

Pada iterasi 2, diperoleh pengelompokan-pengelompokan data yang sama. Untuk pencemaran air tingkat tinggi (C1) ada pada provinsi Sumatera Utara, Jawa Barat, Jawa Tengah, Jawa Timur, untuk pencemaran air tingkat rendah (C2) ada pada provinsi Aceh, Sumatera Barat, Riau, Jambi, Sumatera Selatan, Bengkulu, Lampung, Kep.Bangka Belitung, Kep.Riau, DKI Jakarta, DI Yogyakarta, Banten, Bali, Nusa Tenggara Barat, Nusa Tenggara Timur, Kalimantan Barat, Kalimantan Tengah, Kalimantan Selatan, Kalimantan Timur, Kalimantan Utara, Sulawesi Utara, Sulawesi Tengah, Sulawesi Selatan, Sulawesi Tenggara, Gorontalo, Sulawesi Barat, Maluku, Maluku Utara, Papua Barat, Papua. Proses k-means berhenti karena data antara iterasi saat ini dan iterasi sebelumnya memiliki pengelompokan yang sama.

\section{KESIMPULAN}

Berdasarkan pernilaian terhadap pemanfaatan datamining pada pengelompokan provinsi terhadap pencemaran lingkungan hidup menggunakan algoritma $K$-means clustering dapat diterapkan. Hasil perhitungan dan hasil aplikasi Rapidminer sama. Data dikelompokkan menjadi 2 cluster yaitu provinsi yang memiliki pencemaran air tingkat tinggi(C1) dan provinsi yang memiliki pencemaran air tingkat rendah(C2). Dengan menggunakan nilai centroid awal pada iterasi 1 untuk pencemaran air tingkat tinggi(C1) 1900, pencemaran air tingkat rendah(C2) 55. Algoritma K-Means clustering pada penelitian ini menghasilkan 2 iterasi, sehigga diperoleh hasil akhir yaitu: untuk pencemaran air tingkat tinggi (C1) ada pada provinsi Sumatera Utara, Jawa Barat, Jawa Tengah, Jawa Timur, untuk pencemaran air tingkat rendah (C2) ada pada provinsi Aceh, Sumatera Barat, Riau, Jambi, Sumatera Selatan, 
Bengkulu, Lampung, Kep.Bangka Belitung, Kep.Riau, DKI Jakarta, DI Yogyakarta, Banten, Bali, Nusa Tenggara Barat, Nusa Tenggara Timur, Kalimantan Barat, Kalimantan Tengah, Kalimantan Selatan, Kalimantan Timur, Kalimantan Utara, Sulawesi Utara, Sulawesi Tengah, Sulawesi Selatan, Sulawesi Tenggara, Gorontalo, Sulawesi Barat, Maluku, Maluku Utara, Papua Barat, Papua.

\section{REFERENCES}

[1] S. M. Dewi and A. P. Windarto, "Analisis Metode Electre Pada Pemilihan Usaha Kecil Home Industry Yang Tepat Bagi Mahasiswa," Sist. J. Sist. Inf., vol. 8, no. 3, pp. 377-385, 2019.

[2] D. R. S. P, A. A. Muin, and M. Amin, "PEMILIHAN FACIAL WASH UNTUK KULIT WAJAH BERMINYAK DENGAN METODE PROMETHEE II,” CESS (Journal Comput. Eng. Syst. Sci., vol. 4, no. 2, pp. 222-229, 2019.

[3] C. Astria, A. P. Windarto, and Z. Musiafa, "PEMILIHAN PRODUK SAMPO SESUAI JENIS KULIT KEPALA DENGAN METODE PROMETHEE II," CESS (Journal Comput. Eng. Syst. Sci., vol. 4, no. 2, pp. 178-185, 2019.

[4] D. N. Batubara, A. P. Windarto, and M. R. Raharjo, "PENERAPAN PROMETHEE II PADA PEMILIHAN PRODUK CONDITIONER SEBAGAI UPAYA PENINGKATAN MINAT BELI KONSUMEN," CESS (Journal Comput. Eng. Syst. Sci., vol. 4, no. 2, pp. 191-197, 2019.

[5] D. N. Batubara, D. R. S. P, and A. P. Windarto, "Penerapan Metode PROMETHEE II Pada Pemilihan Situs Travel Berdasarkan Konsumen,” J. SISFOKOM, vol. 8, no. 1, pp. 46-52, 2019.

[6] A. P. Windarto, "Penerapan Datamining Pada Ekspor Buah-Buahan Menurut Negara Tujuan Menggunakan K-Means Clustering Method," Techno.Com, vol. 16, no. 4, pp. 348-357, 2017.

[7] M. G. Sadewo et al., "PENERAPAN ALGORITMA CLUSTERING DALAM MENGELOMPOKKAN BANYAKNYA DESA / KELURAHAN MENURUT UPAYA ANTISIPASI / MITIGASI BENCANA ALAM MENURUT PROVINSI DENGAN K-MEANS,” vol. 2, pp. 311-319, 2018.

[8] H. Siahaan, H. Mawengkang, S. Efendi, A. Wanto, and A. P. Windarto, "Application of Classification Method C4 . 5 on Selection of Exemplary Teachers," in IOP Conference Series, 2018, pp. 1-6.

[9] Sudirman, A. P. Windarto, and A. Wanto, "Data mining tools | rapidminer: K-means method on clustering of rice crops by province as efforts to stabilize food crops in Indonesia," IOP Conf. Ser. Mater. Sci. Eng., vol. 420, p. 12089, 2018.

[10] S. Azhar, H. Latipa, S. Leni, and N. Zulita, "Sistem Pakar Penyakit Ginjal Pada Manusia Menggunakan Metode Forward Chaining," J. Media Infotama, vol. 10, no. 1, pp. 16-26, 2014.

[11] T. Budiharjo, Soemartono, T., Windarto, A.P., Herawan, "Predicting tuition fee payment problem using backpropagation neural network model," Int. J. Adv. Sci. Technol., 2018.

[12] T. Budiharjo, Soemartono, T., Windarto, A.P., Herawan, "Predicting school participation in indonesia using back-propagation algorithm model," Int. J. Control Autom., 2018.

[13] A. P. Windarto, M. R. Lubis, and Solikhun, "MODEL ARSITEKTUR NEURAL NETWORK DENGAN BACKPROPOGATION PADA PREDIKSI TOTAL LABA RUGI KOMPREHENSIF BANK UMUM KONVENSIONAL," Kumpul. J. Ilmu Komput., vol. 5, no. 2, pp. 147-158, 2018.

[14] A. P. Windarto, M. R. Lubis, and Solikhun, "IMPLEMENTASI JST PADA PREDIKSI TOTAL LABA RUG KOMPREHENSIF BANK UMUM KONVENSIONAL DENGAN BACKPROPAGATION," J. Teknol. Inf. dan Ilmu Komput., vol. 5, no. 4, pp. 411-418, 2018.

[15] Sumijan, A. P. Windarto, A. Muhammad, and Budiharjo, "Implementation of Neural Networks in Predicting the Understanding Level of Students Subject," Int. J. Softw. Eng. Its Appl., vol. 10, no. 10, pp. 189-204, 2016.

[16] B. M. Metisen and H. L. Sari, "Analisis Clustering Menggunakan Metode K-Means dalam Pengelompokkan Penjualan Produk pada Swalayan Fadhila," J. Media Infotama, vol. 11, no. 2, pp. 110-118, 2015.

[17] M. G. Sadewo, A. P. Windarto, and S. R. Andani, "Pemanfaatan Algoritma Clushtering Dalam Mengelompokkan Jumlah Desa / Kelurahan Yang Memiliki Sarana Kesehatan," vol. I, pp. 124-131, 2017.

[18] J. Nasional and S. Informasi, "PENERAPAN DATA MINING DALAM PENGELOMPOKAN PENDERITA THALASSAEMIA," vol. 2, pp. 299-305, 2017.

[19] M. Anjelita, A. P. Windarto, and A. Wanto, "Analisis Metode K-Means pada Kasus Ekspor Barang Perhiasan dan Barang Berharga Berdasarkan Negara Tujuan," pp. 476-482, 2019.

[20] C. Hijau, "PENERAPAN DATA MINING DENGAN METODE CLUSTERING," vol. 1, no. Senatkom, 2015.

[21] S. Defiyanti, M. Jajuli, T. Informatika, F. Ilmu, K. Universitas, and S. Karawang, "IMPLEMENTASI ALGORITMA KMEANS DALAM,”vol. I, no. 2, pp. 62-68, 2015. 